\title{
The Factors of Modern Competetiveness
}

\author{
Anna A. Khryseva \\ Volgograd State Technical University \\ Olga N. Korzhenevskaya
}

Volgograd State Technical University

Olga A. Savchenko

Volgograd State Technical University

\author{
Doi:10.5901/mjss.2015.v6n5s2p411
}

\begin{abstract}
The world market today is a major component of the world economy which is composed of the general publics' sphere of demand and the supply and exchange of commodities and services. It also includes commodity-money relations between countries which are connected to participation in the international division of labour. World economic relations are expanding and national borders are constantly being altered owing to the development of globalization. Countries which engage in such market exchanges mutually benefit one another while economically weak ones have a lot of drawbacks. This is because they cannot withstand the competition, which due to processes of globalization is increasing and reaching a "Hyper" level. This article is devoted to analysis of competitiveness of business structures in Russia in globalization conditions. The publication focuses on the development of transnational corporations amidst hyper-competitive conditions. Specific problems and prospective solutions are mentioned which Russia has been forced to in the 21 century. Nowadays it is paid a big attention to the branches which are connected with information technology. Thus, Russia that is rich in a vast reserve of scientists and various technical and scientific organizations has benefits in this field. Russian enterprises may get advantages from the globalization processes and raise their position in the world economics.
\end{abstract}

Keywords: competitiveness, globalization, transnational corporations, innovations, business structures.

\section{Introduction}

The world market today is a major component of the world economy which is composed of the general publics' sphere of demand and the supply and exchange of commodities and services. It also includes commodity-money relations between countries which are connected to participation in the international division of labour. World economic relations are expanding and national borders are constantly being altered owing to the development of globalization. Thus, the global commodity markets are formed where each country represents its particular products while purchasing the goods and services which it cannot produce itself. There are many different types of commodity markets such as large groups of foodstuffs and raw materials, machinery and equipment, textiles etc. Countries which engage in such market exchanges mutually benefit one another while economically weak ones have a lot of drawbacks. This is because they cannot withstand the competition, which due to processes of globalization is increasing and reaching a "Hyper" level. Modern tendencies of globalization are the dynamism and the aggressiveness to some extent, because domestic competitors from one country are joining foreign competitors. As a consequence, the processes of globalization are favorable for consumers because of the abundance of products.

It's safe to say that globalization is changing not only the traditional ideas of terms such as labour, productivity, and production costs, but globalization is also altering the conditions of competition.

The problem with improving the level of competitiveness of business structures typically changes the business entirely due to the presence of the capital world market, computer market, and labour market. "According to some researchers competitive advantage can be achieved through the creation and development of some distinctive qualities of products which are valued by consumers. This should be done by usage of distinctive capabilities of the organization, rather than by technology and resources which are accessible to it». (Efremov, 2009). 


\section{Literature Review}

This article is devoted to analysis of competitiveness of business structures in Russia in globalization conditions. The publication focuses on the development of transnational corporations amidst hyper-competitive conditions. Specific problems and prospective solutions are mentioned which Russia has been forced to in the 21 century.

The globalization is a result of modern development of the world economy, which is influenced by the transnational corporations (TNCs). They play a leading role in the development of world economic relations, implementing the global strategy and forming the external conditions of international companies. Innovations, the possession of information and exchange of technology, have become a driving force for development and progress. In the competition for new markets, such companies are able to invest successfully and heavily in RACE (Research into Advanced Communications for Europe), and they are also able to create a brand new unique product that will soon be in popular demand in the market. Such huge investments allow to countries increase their future economic growth prospects. Statistics show that the largest TNCs are so enormous that they are wealthier than some countries.(Gribtsova, 2011).

From a list of 100 of the largest economics in the world, 52 are transnational corporations and respectively 48 are States. More than two thirds of foreign trade and nearly half of the world's production are controlled by TNCs. These organizations control about $80 \%$ of innovations and "know-how". The total volume of accumulated direct foreign investments exceeds four trillion dollars. A total volume of sales which are made by TNCs is $25 \%$ of the world. All of the accumulated sales of TNC's global structures are above all the world's exports. For example, a half of the export operations in the United States are held by American and foreign TNCs. In the United Kingdom of Great Britain similar operations are carried out and up to $80 \%$ TNCs. In Singapore - up to $90 \%$.

Transnational corporations are in the process of seeking to update their products with lower costs and better consumer properties while using various innovative elaborations and modern technology to increase their competitiveness.

A sharp increase in competition affects globalization changes. This leads to a hyper competition with similar companies through the monopolization of markets and the usage of socio-economic imbalances of market segments. The aim of hyper competition is the removal of the branch boundaries. First, the boundaries are blurred between the different sectors in favor of their associations, such as insurance and banking sector. Secondly, intra-industry boundaries are removed, for instance as in the automotive industry, which campaigns are trying to expand the range of products.

The reason of dynamic of hyper-competition is probably because of the appearance of virtual enterprises. This means there is the association of a unique experience and modern technologies of several companies for solving a specific project which cannot be implemented by each of them separately. A virtual company also produces goods and makes services, but these processes occur more quickly.

It becomes necessary for companies to look for certain opportunities to increase competitive advantage and create new conditions for them in such competitive world. A modern innovative marketing might be an instrument. It lets companies explore and predict the behavior of partners, competitors and consumers, as well as have an influence on them.

What trends can be marked at the present stage of development of TNCs?

The typical, but at the same time, the most important trend is the integration of large companies with similar products. Transnational companies might also buy smaller foreign campaigns. For instance, French company L'Oreal has acquired American brand Maybelline.

Another important trend is the decrease in costs and therefore increase in the profits of large TNCs at the expense of manufacturing their product in other countries. The labor is relatively cheaper there. For example, a huge Apple corporation carried out the production of goods to China.

There also might be marked other trends.

1) The increase in the number of small firms due to the fact that the diversity of information and certain network technologies allows them almost on almost equal conditions compete with larger companies for consumers. This practice is not only done in one particular country but also at a global level.

2) The role of the state as an integrating regulator of the economy increases and it becomes the world entrepreneur.

3) An active participation of transnational corporations in the global innovation structure with the creation of a «cloud» information network which increases the importance of research and development, as well as the growth of intangible assets in its capital.

A foreign economic situation in Russia is discussed broadly today not only in the government but also on lectures at universities. This theme is topical because it is connected with such important indicators as, for example, the level of 
labour force. At present times a market economics is dynamic and impetuous. A success of subject's commodity-money relations is influenced by its competitiveness. It does not matter if this subject is an enterprise of small business or it is an economics of the whole State.

To begin with, it is worth to define what the term of competitiveness means. First of all, it is the competitiveness of the country, which is the resultant and relative indicator. It shows the efficiency of production, distribution and sales of goods in the country and abroad. It also raises the economic potential and the level of socio-economic development.

Country competitiveness is a measure which combines the competitiveness of commodities and industry competitiveness. It also defines the level of economic development of the country among others in the world market. Country competitiveness is the ability of the particular country produce goods and services which satisfy the requirements of the world market. Moreover it increases the welfare of the country and its citizens.

Competitiveness becomes the most important factor of the work of business structures due to the fact that manufacturers are trying to attract new customers and hold long-time ones and improve methods of a competitive struggle. In addition to this, they are contending for the increase in demand and the increase in its market share.

There are some factors which influence on the competitiveness of business organizations. They can be divided into external and internal and these factors can be defined according to their macro and micro conditions.

The external factors include:

1. State factors, including economic instruments (tax policy, depreciation policy, investment policy and financial policy), the legislative power plays the important role.

2. Market factors (type and size of the market, competitors, labour market, labour force, income level, industry characteristics).

3. Socio-political factors (social organizations, cultural level, political stability, social status).

The internal factors include:

- Organizational structure of the enterprise (production and technological potential, marketing services and logistics);

- Innovative potential (skilled personnel, system of standards and certification, control and analysis of innovations);

- The quality of exploitation and service (packaging, storage, environmentally friendly products, transportation products and recycling system). (Svetlov, 2008).

The success of an entrepreneur depends on many factors. One of them is the internal business environment, which depends primarily on the entrepreneur's knowledge, experience, and skills in doing business. Another factor is the external environment, because the growing process of globalization makes the tough terms of survival, existence and dominance. It changes the dynamics, the methods and the form of competitive struggle and the competitiveness of enterprises, countries and industries. That is why it is necessary to take every measure for the development of Russian business and the increase in its competitiveness in the global market. In the world commodity turnover, the share of Russia is $3 \%$. There are about 7.5 million business organizations in Russia, but only $1 \%$ of them are working in the global market. Consequently, the measures for increasing exports are a priority. Special attention should be paid to increasing exports of products which are manufactured with a high technology. Nowadays this way can make a progress in the society and the economics of certain countries.

To identify the actual level of competitiveness of Russian business it is necessary to mark the benefits and weaknesses of Russian economics in the world market.

Russia differs from other democratic countries by its monopolization of the market. The cost of labor increases. Moreover, the products are inferior in quality to foreign ones due to the fact that innovations are not used to modernize the production. Therefore, Russian producers have losses in the external market.

It might be considered surprising in the market economy that Russian society is forced to make mechanisms of state compulsion to innovative behavior of economic agents. This situation reminds the policy of innovations' development in the Soviet period. However, the difference from the expected effect is significant. This is because the variety of economic relations was obeyed orders while the existing of the Soviet Union. Promotion of innovative activities has been achieved with difficulties and under a total control. The second reason is that the market forces for innovations itself in the market economy but it is not developed enough in Russia. Furthermore, the government has less chance to get the expected effect today than in a planned economy, because it is impossible to force private entrepreneurs to use innovations. Motivation and incentives have become necessary.

The competitiveness of Russian business is characterized by:

- The lag of industries from foreign similar productions;

- Minimum share of products from innovative production; 
- The predominance of production of hydrocarbons in the structure of the economy;

- Imperfection of the tax legislation;

- Lack of an effective system of direct incentives.

It is considered that the interaction of all economic actors is held on a mutually beneficial basis. Even if the economic agents make a compromise, they wish to have favorable conditions for the implementation of their economic interests. Otherwise, some imbalances in economic freedoms of agents will decrease the business interest in achieving better results.

\section{Results}

We consider that business structures won't be responsible for the realization of public interests until the government undertakes the regulation in full. Gradual forming of the sense of responsibility can be achieved by self-regulatory organizations with well-qualified entrepreneurs. The business shouldn't give advice to incompetentofficials. It has to strengthen the economic position in the home and foreign markets. However, the business is forced to "buy" an administrative resource to avoid inefficient and delayed decisions, which make "hothouse" conditionsfor certain entrepreneurs. Consequently, low competence of employee brings a lot of losses to the State. Moreover, this reduces the whole competitiveness of Russian business. Nowadays, it is necessary to create economic models which support marketoriented business strategies, such as an internationalization strategy or a strategy of increasing competitiveness in Russia. The government's previously proposed model of a small business support is not working due to lagging modernization of institutions.

The main aim of Russian business is the usageof one of the dominant competitive advantages of the country which is a large home market. It is necessary to fill it with top - quality goods produced by the real sectors of Russian economics. Another aim is maintaining the balance and stability in the market and in the whole economics of the country as well as caring about the consumers' needs. There are some purposes.

First, the loans should be available for all entrepreneurs to make new competitive terms of business financing. This is because the interest rates of loans often exceed the profitability of projects.

Secondly, we need to develop the infrastructure. It is necessary to use the tools of public-private partnerships broadly. This should be done not only on Federal principles but also on Regional ones.

Thirdly, the priority is the preparation of well- qualified specialists for the real sector of economics becausethe success of Russian business will depend on their work. (The Meeting of the State Council, 2014).

\section{Conclusion}

To sum up, Russia has good material and technical conditions and intellectual and human potential for the successful transformation in the post-industrial society. Nowadays it is paid a big attention to the branches which are connected with information technology. Thus, Russia that is rich in a vast reserve of scientists and various technical and scientific organizations has benefits in this field. Russian enterprises may get advantages from the globalization processes and raise their position in the world economics. In order to increase the level of competitiveness they should outsource certain business functions to other organizations which are able to implement them more effectively or participate in networking corporations. Moreover, the role of the state is very significant in this field. It should support strongly developing branches of industry with various subsidies and benefits.

\section{References}

Efremov V. S. Strategic planning in business systems. M.: Inpress, 2009. - 238 p.

Gribtsova Maria.10 corporations which lead the world [Electronic resource] // Inside the business. - Mode of access: <http://www.rb.ru/ article/korporatsii-kotorye-pravyat-mirom/6756067.html/>. - Access Date: 15.08. 2011

Svetlov G. V. Themain factors of competitiveness and the types of competitive advantages of business organizations//Creative economics. 2008. №5. p. 78.

The Meeting of the State Council. - Mode of access: <http://www.kremlin.ru/news/46636/>. - Access Date: 18.09.2014 